\title{
THE SOFFER TEST IN ESSENTIAL HYPERTENSION
}

\author{
BY FRANK LONDON AND LUTHER L. TERRY \\ (From the Cardiovascular Clinic [Section of General Medicine and Experimental Therapeutics \\ of the National Heart Institute] and the Medical Service, U. S. Public \\ Health Service Hospital, Baltimore, Maryland)
}

(Submitted for publication July 13, 1951 ; accepted October 15, 1951)

The hypertension occurring in association with adrenal cortical hyperfunction (Cushing's syndrome and congenital adrenal hyperplasia), the difficulty in establishing or maintaining experimental hypertension in the absence of the adrenal gland (1-3), and the amelioration of human "essential" hypertension by adrenalectomy (4) or the development of adrenal insufficiency (5) have led several investigators $(6-8)$ to suggest that adrenal hyperfunction might contribute to the pathogenesis of human "essential" hypertension.

Attempts by a number of investigators to demonstrate this hyperfunction have been unsuccessful. Selye (9), Bruger, Rosenkrantz and Lowenstein (10), and Daughaday, Jaffe and Williams (11) have found the analysis of metabolic excretory products of the adrenal cortex (17-ketosteroids and 11-oxysteroids) in the urine of patients with hypertension to yield normal or low values. Careful study of carbohydrate metabolism in patients with hypertension (12) by means of the insulin tolerance test has revealed no abnormalities. Nitrogen balance is easily maintained in hypertensive subjects with a small protein intake (13). We and others (14) have found the blood eosinophil count normal in hypertension. Schroeder, Davies and Clark (15) have shown that the excretion of sodium in the sweat is normal in ordinary essential hypertension.

The renaissance of interest in the therapeutic efficacy of a low sodium regime in the treatment of hypertension has focused attention particularly on the electrolyte controlling properties of the adrenal cortex as a possible mechanism for adrenal contribution to the pathogenesis of hypertension. The plasma electrolyte abnormality (hypochloremic alkalosis) frequently seen in Cushing's syndromè is not seen in hypertension. Most observers have found no plasma electrolyte abnormality in hypertension although Selye (9) believes the ratio of sodium to chloride is high.
Soffer and his associates $(16,17)$ have pointed out that patients with Cushing's syndrome have an abnormal response to salt loading and the administration of desoxycorticosterone. His normal individuals, after a given salt load, retained more of the salt after the administration of desoxycorticosterone than they did without this drug. On the other hand, the patients with Cushing's syndrome showed an increased "diuresis" of the salt load after desoxycorticosterone. This observation has been confirmed by others $(18,19)$.

It is conceivable, then, that should patients with essential hypertension have adrenal cortical hyperfunction with respect to electrolyte metabolism they would exhibit this same abnormal response.

\section{METHODS}

The salt loading tests were carried out on a group of patients with hypertension following the exact regime outlined by Soffer. The patients were permitted no food during the morning of the test and no fluid after 7 p.m. the night before. At 6 a.m. on the morning of the studies a urine specimen was collected and discarded. The patient was then given $500 \mathrm{cc}$. of water to drink at one time, and all the urine voided was collected over a three hour period to 9 a.m. At 9 a.m., 200 cc. of $5 \%$ saline (171 milliequivalents of sodium and of chloride) were injected intravenously and the urine voided the next three hours was collected. Two days later the same procedure was repeated, except that at 10 p.m. on the previous evening the patient was injected with $10 \mathrm{mgm}$. of desoxycorticosterone acetate (DCA). The urine volume for each period was measured and sodium and chloride determinations were made on each specimen. Sodium was determined by flame photometry and chlorides according to the method of Van Slyke and Hiller (20).

The hypertensive patients used in this study were 10 ambulatory male patients chosen from the outpatient clinic according to the following criteria: a history in any way suggestive of congestive heart failure, abnormal urinary sediments, or elevated blood urea nitrogen were causes for exclusion. After selection, patients were placed on restricted activity in the hospital and blood pressure determined twice daily at $6 \mathrm{a.m}$. and $6 \mathrm{p.m}$. in the recumbent position for seven days. Any blood pres- 
TABLE I

\begin{tabular}{|c|c|c|c|c|c|c|c|c|c|c|c|c|}
\hline \multirow{3}{*}{ Subj. } & \multicolumn{4}{|c|}{ Control } & \multicolumn{4}{|c|}{ After injection of $10 \mathrm{mgm}$. of $D C A$} & \multicolumn{4}{|c|}{ Excretion } \\
\hline & \multirow{2}{*}{$\begin{array}{l}\text { Urine } \\
\text { vol. } \\
6-9 \\
\text { a.m. }\end{array}$} & \multirow{2}{*}{$\begin{array}{l}\text { Urine } \\
\text { vol. } \\
9-12 \\
\text { a.m. }\end{array}$} & \multirow{2}{*}{$\begin{array}{c}\text { Injected } \\
\text { Na } \\
\text { Excreted } \\
\mathrm{Na}_{0}\end{array}$} & \multirow{2}{*}{$\begin{array}{c}\text { Injected } \\
\mathrm{Cl} \\
\text { Excreted } \\
\mathrm{Cl}_{0}\end{array}$} & \multirow{2}{*}{$\begin{array}{l}\text { Urine } \\
\text { vol. } \\
6-9 \\
\text { a.m. }\end{array}$} & \multirow{2}{*}{$\begin{array}{l}\text { Urine } \\
\text { vol. } \\
9-12 \\
\text { a.m. }\end{array}$} & \multirow{2}{*}{$\begin{array}{l}\text { Injected } \\
\text { Na } \\
\text { Excreted } \\
\text { Nad }\end{array}$} & \multirow{2}{*}{$\begin{array}{c}\text { Injected } \\
\mathbf{C l} \\
\text { Excreted } \\
\mathbf{C l}_{\mathbf{d}}\end{array}$} & \multicolumn{2}{|c|}{ Decrease } & \multicolumn{2}{|c|}{ Increase } \\
\hline & & & & & & & & & $\frac{\begin{array}{l}100 \times \\
\left(\mathrm{Na}_{0}-\mathrm{Nad}\right)\end{array}}{\mathrm{Na}_{0}}$ & $\frac{\underset{\left(\mathrm{Cl}_{\sigma}-\mathrm{Cl}_{\mathrm{d}}\right)}{\mathrm{Cl}_{0}}}{{ }^{100}}$ & $\begin{array}{l}100 \times \\
\frac{\left.(\mathrm{Nad}-\mathrm{Na})_{c}\right)}{N a_{0}}\end{array}$ & $\frac{\underset{100 \times}{\left(\mathrm{Cl}_{\mathrm{d}}-\mathrm{Cl}_{\mathrm{c}}\right)}}{\mathrm{Cl}_{\mathrm{c}}}$ \\
\hline $\begin{array}{l}\text { P. R. } 1 \\
\text { P. R. } 2 \\
\text { T. R. } 1 \\
\text { T. R. } 2 \\
\text { V. A. } 1 \\
\text { V. A. } 2 \\
\text { H. K. } \\
\text { L. E. } \\
\text { B. E. } \\
\text { M. C. } \\
\text { H. N. } \\
\text { D. E. } \\
\text { T. S. }\end{array}$ & $\begin{array}{l}c c . \\
275 \\
325 \\
275 \\
335 \\
100 \\
49 \\
250 \\
254 \\
520 \\
510 \\
320 \\
215 \\
195\end{array}$ & $\begin{array}{l}c c . \\
675 \\
850 \\
200 \\
195 \\
125 \\
245 \\
275 \\
462 \\
630 \\
310 \\
180 \\
315 \\
253\end{array}$ & $\begin{array}{c}19.8 \% \\
48.5 \\
8.2 \\
8.8 \\
2 \\
23.3 \\
16.9 \\
35.2 \\
{[39.4} \\
19 \\
13.1 \\
21.3 \\
11.1\end{array}$ & $\begin{array}{c}20.1 \% \\
36 \\
5.2 \\
10.3 \\
3 \\
26.4 \\
15.6 \\
35.2 \\
40.3 \\
3.7 \\
14.8 \\
23.8 \\
10.2\end{array}$ & $\begin{array}{r}c c . \\
150 \\
515 \\
240 \\
208 \\
90 \\
74 \\
76 \\
190 \\
400 \\
440 \\
290 \\
490 \\
166\end{array}$ & $\begin{array}{l}c c . \\
700 \\
673 \\
150 \\
130 \\
250 \\
130 \\
140 \\
470 \\
595 \\
185 \\
130 \\
169 \\
213\end{array}$ & $\begin{array}{r}19 \% \\
39.4 \\
-3.3 \\
5.3 \\
19.7 \\
4.3 \\
8.1 \\
22.4 \\
23.5 \\
4.2 \\
9.6 \\
-1.1 \\
8.8\end{array}$ & $\begin{array}{r}21.9 \% \\
28.3 \\
2.9 \\
7.4 \\
16.9 \\
7.9 \\
7.0 \\
22.5 \\
16.8 \\
1.7 \\
6.8 \\
-6.3 \\
11.1\end{array}$ & $\begin{array}{c}4 \% \\
18.8 \\
140 \\
39.8 \\
\\
82 \\
52.1 \\
36.4 \\
40.4 \\
77.8 \\
26.7 \\
105 \\
20.7\end{array}$ & $\begin{array}{l}\overline{21.4} \\
44 \\
28.2 \\
\\
70.1 \\
55 \\
36.3 \\
58.3 \\
54.0 \\
54 \\
126\end{array}$ & $\begin{array}{l}- \\
- \\
-\end{array}$ & $\begin{array}{l}8.2 \% \\
= \\
2\end{array}$ \\
\hline
\end{tabular}

sure reading below $160 / 105 \mathrm{~mm}$. $\mathrm{Hg}$ during this period or during the subsequent study period disqualified the patient. The patients were also placed on diets containing at least $5 \mathrm{gm}$. of salt daily for four days prior to the test. The age distribution of these patients varied from 33 to 65 with a mean age of 51.5 years.

\section{RESULTS}

In Table I are charted the data from 13 complete tests on ten male patients with essential hypertension. For convenience and ease of comparison with Soffer's data, these data are charted in the same fashion. It must be realized that the frgures in the last two columns do not represent absolute decrease or increase of sodium or chloride excretion in milliequivalents but only percentage of change between the control and the DCA period. Nevertheless, they effectively demonstrate the retention or diuresis of sodium and chloride in a given patient. In view of the fact that the test only assesses the excretion of sodium and chloride for the first three hours after the administration of the load, it is doubtful that plotting excretion changes in milliequivalents would be of any more value. Despite its obvious shortcomings, the fact that this test clearly demonstrates the electrolyte abnormality in most cases of Cushing's syndrome makes its use seem worthwhile in clinical evaluation of a possible adrenal controlled electrolyte abnormality in essential hypertension.

It is evident that nine of the ten patients responded with a clear-cut retention of sodium and chloride after DCA which is the normal response. One patient (V. A. 1) showed a very low control excretion of sodium and chloride which was responsible for an apparent salt diuresis. When this test was repeated with more normal control excretion he showed the normal retention effect with DCA.

\section{SUMMARY AND CONCLUSIONS .}

1. The Soffer salt tolerance test was carried out 13 times in ten selected patients with hypertension.

2. Nine of the ten patients showed a retention of chloride and all ten of the patients a retention of sodium after salt loading and DCA. This is a normal response.

3. These data fail to demonstrate an electrolyte abnormality in essential hypertension similar to that found in patients with adrenal cortical hyperfunction of the Cushing type.

\section{REFERENCES}

1. Goldblatt, H., Studies on experimental hypertension; pathogenesis of experimental hypertension due to renal ischemia. Ann. Int. Med., 1937, 11, 69.

2. Page, I. H., The effect of bilateral adrenalectomy on arterial blood pressure of dogs with experimental hypertension. Am. J. Physiol., 1938, 122, 352.

3. Collins, D. A., and Wood, E. H., Experimental renal hypertension and adrenalectomy. Am. J. Physiol., 1938, 123, 224.

4. Green, D. M., Nelson, J. N., and Dodds, G. A., Effects of adrenal resection on hypertension and diabetes. Federation Proc., 1949, 8, 60. 
5. Perera, G. A., The relationship of the adrenal cortex to hypertension; observations on the effect of hypoadrenalism on a patient with hypertensive vascular disease. J.A.M.A., 1945, 129, 537.

6. Perera, G. A., The adrenal cortex and hypertension. Bull. New York Acad. Med., 1950, 26, 75.

7. Alexander, A. S., and Young, R. W., Hypertension treated by irradiation of the adrenals; with report of 23 cases. New Orleans M. \& S. J., 1949, $101,536$.

8. Crile, G. W., Indications and contraindications for denervation of the adrenal glands. Ann. Surg., 1934, 100, 667.

9. Selye, F. L., Biochemical changes in hypertension. Canad. M. A. J., 1947, 57, 325.

10. Bruger, M., Rosenkrantz, J. A., and Lowenstein, B. E., Studies on morphology of adrenal cortex and on excretion of 17-ketosteroids in hypertensive patients. Am. J. M. Sc., 1944, 208, 212.

11. Daughaday, W. H., Jaffe, H., and Williams, R. H., Adrenal cortical hormone excretion in endocrine and non-endocrine disease as measured by chemical assay. J. Clin. Endocrinol., 1948, 8, 244.

12. Mirsky, I. A., Kaplan, S. M., Podore, C. J., and Broh-Kahn, R. H., The insulin tolerance test in patients with essential hypertension. J. Clin. Invest., 1950, 29, 297.

13. Watkin, D. M., Froeb, H. F., Hatch, F. T., and Gutman, A. B., Effects of diet in essential hypertension. II. Results with unmodified Kempner rice diet in fifty hospitalized patients. Am. J. Med., 1950, 9, 441.

14. Laragh, J. H., and Almy, T. P., Changes in circulating eosinophils in man following epinephrine, insulin, and surgical operations. Proc. Soc. Exper. Biol. \& Med., 1948, 69, 499.

15. Schroeder, H. A., Davies, D. F., and Clark, H. E., A syndrome of hypertension, obesity, menstrual irregularities, and evidence of adrenal cortical hyperfunction. Proc. Central Soc. Clin. Research, 1949, 22, 73 ; J. Lab. \& Clin. Med., 1949, 34, 1746.

16. Soffer, L. J., Lesnick, G., Sorkin, S. Z., Sobatka, H. H., and Jacobs, M., The utilization of intravenously injected salt in normals and in patients with Cushing's syndrome before and after the administration of desoxycorticosterone acetate. J. Clin. Invest., 1944, 23, 51.

17. Soffer, L. J., Gabrilove, J. L., and Jacobs, M. D., Further studies with the salt tolerance test in normal individuals and in patients with adrenal cortical hyperfunction. J. Clin. Invest., 1949, 28, 1091.

18. Thorn, G. W., Merrill, J. P., Smith, S., Roche, M., and Frawley, T. F., Clinical studies with ACTH and cortisone in renal disease. Arch. Int. Med., 1950, 86, 319.

19. Cargill, W. H., and St. John, H. A., Desoxycorticosterone and the urinary excretion of sodium chloride. Am. J. Med., 1950, 9, 395.

20. Van Slyke, D. D., and Hiller, A., Application of Sendroy's iodometric chloride titration to proteincontaining fluids. J. Biol. Chem., 1947, 167, 107. 